Pyrmont/MVZ Weserbergland, Rheumatology and Immunology, Hannover; Bad Pyrmont, Germany

Background: Axial spondyloarthritis (axSpA) is a chronic inflammatory condition often associated with impaired working participation ${ }^{1}$ not only translating to devastating outcomes for patients (pts) but also increased economic and social burden due to a significant amount of indirect costs. Data on the different work participation domains in axSpA pts with access to biologic therapies are limited. Objectives: To characterise the different domains of work participation [presenteeism, absenteeism, sick leave, unemployment, disability pensions] in axSpA pts and their associations with demographic and clinical confounders

Methods: Pts with confirmed clinical diagnosis of axSpA were enrolled in a multicenter, observational ATTENTUS survey conducted across Germany (Nov2019 to Jul-2020). To ensure high data quality, inclusion criteria was verified by external monitoring, followed by evaluation of the domains of impaired work participation, including absenteeism and presenteeism (WPAI). Demographics, clinical parameters and patient related outcomes (PROs) were collected via tablet. This analysis included working age (18-65 years) pts; and excluded students and retired pts. Pts without absenteeism (value $=0$ ) and presenteeism $\leq 20 \%$ were defined as no impairment at work.

Results: A total of 787 axSpA pts were enrolled in the survey. Seven students, 68 retired pts and 17 pts not fulfilling the inclusion criteria were excluded from this analysis, leaving 695 pts with complete data sets. Baseline data are outlined in Table 1.50 pts received disability pensions, 29 pts received unemployment benefits, 590 (84.9\%) pts reported paid work [part-time: $n=132(22.4 \%)$; fulltime: $n=458(65.9 \%)]$, with $242(41.0 \%)$ pts having no impairments at work. 379 $(64.2 \%)$ employed pts took sick leave within the previous 12 months $(\mathrm{mo})(<3 \mathrm{mo}$ : $\mathrm{n}=351$; 3-6 mo: $\mathrm{n}=17$; $>6 \mathrm{mo:} \mathrm{n}=11)$. Absenteeism and presenteeism occurred in $140(23.7 \%)$ and $496(84.1 \%)$ pts, respectively. Pts without impairments were mostly of young age, male sex, well-educated, with low disease activity, less fatigue and shorter duration of morning stiffness, and preserved global and physical functioning. No apparent differences between pts with and without impairment of work participation were observed in terms of biologic treatment, disease duration and BMI.

Table 1. Descriptive characteristics of the study population

\begin{tabular}{lllll}
\hline Mean (SD), unless specified & $\begin{array}{l}\text { Impaired WP } \\
\mathbf{( n = 4 5 3 )}\end{array}$ & $\begin{array}{l}\text { Full WP } \\
\mathbf{( n = 2 4 2 )}\end{array}$ & p-value & $\begin{array}{l}\text { Total } \\
\mathbf{( n = 6 9 5 )}\end{array}$ \\
\hline Age (yrs) & $46.7(11.1)$ & $42.8(10.1)$ & $<0.001$ & $\begin{array}{l}45.3 \\
(10.9)\end{array}$ \\
& & & & 28.0 \\
BMI & $28.5(14.0)$ & $27.0(6.8)$ & 0.146 & $(12.0)$ \\
& & & & $423(61)$ \\
Male, $\mathrm{n}(\%)$ & $246(54)$ & $177(73)$ & $<0.001$ & $12.6(11.0)$ \\
Disease duration (yrs) & $12.7(11.3)$ & $12.4(10.2)$ & 0.813 & $186(26.8)$ \\
University-Education, $\mathrm{n}(\%)$ & $104(23.0)$ & $82(33.9)$ & $\mathbf{0 . 0 0 1}$ & $469(6.6)$ \\
In a committed relation, $\mathrm{n}(\%)$ & $310(68.4)$ & $159(65.7)$ & 0.464 & $6.5(3.8)$ \\
ASAS-HI & $8.0(3.3)$ & $3.7(3.0)$ & $<0.001$ & $3.9(2.2)$ \\
BASDAI & $4.8(1.9)$ & $2.1(1.6)$ & $<0.001$ & $314(45.2)$ \\
BASDAI > 4, n(\%) & $286(63.1)$ & $28(11.6)$ & $<0.001$ & $4.7(2.5)$ \\
Fatigue [BASDAI \#1] & $5.8(2.1)$ & $2.8(2.1)$ & $<0.001$ & $2.8(2.4)$ \\
Duration morning stiffness & $3.5(2.4)$ & $1.6(1.8)$ & $<0.001$ & \\
$\quad$ [BASDAI \#6] & & & & \\
BASFI & $4.2(2.3)$ & $1.5(1.5)$ & $<0.001$ & $3.3(2.4)$ \\
Biologic treatment, $\mathrm{n}(\%)$ & $230(50.8)$ & $134(55.4)$ & 0.390 & $364(52.4)$ \\
Full time employment, $\mathrm{n}(\%)$ & $256(56.5)$ & $202(83.5)$ & $<0.001$ & $458(65.9)$ \\
Absenteeism & $17.9(32.1)$ & 0 & - & 10.6 \\
& & & & $(26.2)$ \\
Presenteeism & $48.6(21.00)$ & $9.6(8.3)$ & - & 32.6 \\
& & & & $(25.6)$ \\
\hline
\end{tabular}

ASAS-HI, Assessment of SpondyloArthritis International Society-Health Index; BASDAI, Bath Ankylosing Spondylitis Disease Activity Index; BASFI, Bath Ankylosing Spondylitis Functional Index; BMI, basal metabolic index; $n$, number of pts; SD, standard deviation; WP, work productivity; years, yrs

Conclusion: There was a substantial impact on work participation for axSpA pts, despite numerous available therapeutic options. Pts with impaired work participation compared to pts with no impairment, reported increased fatigue, longer duration of morning stiffness, decreased functional capacity, female sex and a lower level of education. REFERENCES:

[1] Ramoda R et al. Arthritis Res Ther. 2016;78

Disclosure of Interests: Uta Kiltz Speakers bureau: AbbVie, Biocad, Chugai, Eli Lilly, Grünenthal, Janssen, MSD, Novartis, Pfizer, Roche and UCB, Consultant of: AbbVie, Biocad, Chugai, Eli Lilly, Grünenthal, Janssen, MSD, Novartis, Pfizer, Roche and UCB, Grant/research support from: Abbvie, Amgen, Biogen, Fresenius, GSK, Novartis and Pfizer, Kirsten Hoeper Speakers bureau: Abbvie, Chugai, Gilead, Lilly, Novartis, Sandoz Hexal and Sanofi. Consultant of: Abbvie, Chugai, Gilead, Lilly, Novartis, Sandoz Hexal and Sanofi. Ludwig Hammel: None declared, Sebastian Lieb Employee of: Employee of Novartis, Andreas Haehle Employee of: Employee of Novartis, Dirk Meyer-Olson Speakers bureau: Abbvie, Amgen, Berlin Chemie, Bristol Myers Squibb, Cellgene, Chugai, Fresenius Kabi, GSK, Jansen
Cilag, Lilly, Medac, Merck Sharp \& Dome, Mylan, Novartis, Pfizer, Sandoz Hexal, Sanofi and UCB, Consultant of: Abbvie, Amgen, Berlin Chemie, Bristol Myers Squibb, Cellgene, Chugai, Fresenius Kabi, GSK, Jansen Cilag, Lilly, Medac, Merck Sharp \& Dome, Mylan, Novartis, Pfizer, Sandoz Hexal, Sanofi and UCB. DOI: 10.1136/annrheumdis-2021-eular.2369

\section{POS0984 AMONG YOUNG PEOPLE CONSULTING BECAUSE OF CHRONIC LOW BACK PAIN IN A UNIVERSITY HOSPITAL IN ARGENTINA}

M. A. Tobar Jaramillo ${ }^{1}$, N. Marin Zucaro ${ }^{1}$, J. Rosa ${ }^{1}$, J. Marin ${ }^{1}$, M. L. Acosta Felquer $^{1}$, L. Ferreyra ${ }^{1}$, J. F. Jaramillo Gallego ${ }^{1}$, J. Marcos ${ }^{2}$, V. Duarte ${ }^{2}$,

E. Soriano ${ }^{1}$. ${ }^{1}$ Hospital Italiano De Buenos Aires, Buenos Aires, Buenos Aires, Argentina; ${ }^{2}$ Novartis, Buenos Aires, Buenos Aires, Argentina

Background: Axial spondyloarthritis ( $\mathrm{SpA})$ is an umbrella term encompassing a number of inflammatory conditions involving the axial skeleton. A substantial delay between disease onset, diagnosis and treatment often occurs, related in part to under-recognition of SpA symptoms. Although several studies have investigated since the publication of the ASAS classification criteria in 2009, the prevalence and incidence of axial SpA in the general population and in patients with SpA-related conditions, the actual prevalence of SpA in many countries (including Argentina) is unknown.

Objectives: To estimate the prevalence of axial SpA and the amount of undiagnosed axial SpA in people under 45 years of age that contacted the health care system for chronic low back pain.

Methods: The setting was a university hospital-based health management organization with a population distribution similary to that of Buenos Aires. All electronic medical records of patients $<45$ years of age at the time of onset of symptoms (as per the ASAS 2009 criteria) and chronic low back pain for 3 or more months) seen at the university hospital-based health management organization between 2009 and 2019, were reviewed. If the patient fulfilled the ASAS criteria, was classified as having axial SpA [ankylosing spondylitis (AS) or non-radiographic axial SpA (nr-axSpA)]. Among this group, if the diagnosis was already established in the medical records by the treating physicians, these patients were also classified as diagnosed with axial $\mathrm{SpA}$; if not, they were classified as undiagnosed with axial $\mathrm{SpA}$. We are reporting the results of descriptive analysis.

Results: A total of 796 patients were included (Table 1), 426 were women (53.52\%, 95\% Cl 50.1-57) with a median age of 34 years (IQR 29-40) at initiation of low back pain with a median follow up of 77.7 months (IQR 35.7-136.4). The prevalence of axial SpA among patients with chronic low back pain was $5.78 \%(\mathrm{n}=46,95 \% \mathrm{Cl} 4.2-7.4) .22$ patients had AS $(2.76 \%, 95 \% \mathrm{Cl} 1.6-3.9)$ with a median lag time between the onset of low back pain and diagnosis of 58.7 months (IQR 33.5 - 92). All AS cases were already diagnosed. 24 patients had nr-axSpA $(3.02 \%, 95 \% \mathrm{Cl} 1.8-4.2)$. Of those, 14 were diagnosed by treating physicians with a lag time median of 23.2 months (IQR 13.1 - 36.5) between the onset of low back pain and diagnosis. Ten patients fulfilled the ASAS criteria $(41.7 \%, \mathrm{Cl} 95 \% 22-61.4)$ but were not diagnosed by the treating physicians (22\%, 95\% Cl 9.82-33.66) among the patients with axial SpA.

Table 1. Demographic, clinical features and therapeutic characteristics of patients with chroniclow back pain stratified by diagnosis

\begin{tabular}{|c|c|c|c|c|c|}
\hline & $\begin{array}{l}\text { Axial spon- } \\
\text { dyloarthritis }\end{array}$ & $\begin{array}{l}\text { Ankylosing } \\
\text { spondylitis }\end{array}$ & $\begin{array}{l}\text { Diagnosed } \\
\text { nr-axSpA }\end{array}$ & $\begin{array}{l}\text { Undiagnosed } \\
\text { nr-axSpA }\end{array}$ & $\begin{array}{l}\text { Other } \\
\text { diagnosis }\end{array}$ \\
\hline & $\mathrm{N}=46$ & $\mathrm{~N}=22$ & $\mathrm{~N}=14$ & $\mathrm{~N}=10$ & $\mathrm{~N}=749$ \\
\hline Female, $\mathrm{n}(\%, \mathrm{Cl})$ & $\begin{array}{l}18 \\
(39.13 \%\end{array}$ & $\begin{array}{l}4 \\
(18.18 \%\end{array}$ & \multicolumn{2}{|c|}{$(71.42 \%, 47.76-(40 \%$, } & $\begin{array}{l}407 \\
(54.34,50.77\end{array}$ \\
\hline Age at chronic LBP & $25.04-53.23)$ & $32.06-34.29)$ & $95.09)$ & $\begin{array}{l}9.63-70.36) \\
39\end{array}$ & $579)$ \\
\hline initiation, years, & $(29.25-40)$ & $(32-40)$ & $(22-36.75)$ & $(35.25-41.5)$ & $(29-40)$ \\
\hline $\begin{array}{l}\text { Followian (IQR) } \\
\text { months (IQR) }\end{array}$ & $\begin{array}{l}88 \\
(33.43-\end{array}$ & $\begin{array}{l}33.67 \\
(23.38-90.34)\end{array}$ & $\begin{array}{l}16.73 \\
(7.64-24.02)\end{array}$ & $\begin{array}{l}64.77 \\
(11.21-164.7)\end{array}$ & $\begin{array}{l}77.69 \\
(35.83-\end{array}$ \\
\hline $\begin{array}{r}\text { Inflammatory chronic } \\
\text { LBP by any criteria }\end{array}$ & $\begin{array}{l}148.66) \\
44(95.7)\end{array}$ & $21(95.5)$ & $13(92.8)$ & $10(100)$ & $\begin{array}{l}135.32) \\
56(7.5 \\
5.6-9.4)\end{array}$ \\
\hline $\begin{array}{l}\mathrm{n}(\%) \\
\text { Seen by a } \\
\text { Rheumatologist, }\end{array}$ & 42 (91.3) & $22(100)$ & $14(100)$ & $6(60)$ & $36(5.1)$ \\
\hline $\begin{array}{l}\text { Lag (io } \\
\text { first LBP to SpA } \\
\text { diagnosis, months, }\end{array}$ & $\begin{array}{l}34.6 \\
(22.6-63.2)\end{array}$ & $\begin{array}{l}58.7(33.5 \\
-92)\end{array}$ & $\begin{array}{l}23.1 \\
(13.1-36.5)\end{array}$ & - & - \\
\hline bDMedian (IQR) & & $10(45$ & $5(36 ; 13-64.9)$ & & - \\
\hline $\begin{array}{l}\text { Lag,time bletween } \\
\text { NSAIDs failure and } \\
\text { first bDMARDs, } \\
\text { months, median } \\
\text { (IQR) }\end{array}$ & 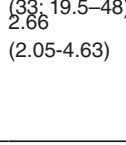 & $\begin{array}{l}24.4-67.8) \\
2.76 \\
(2.07-11.3)\end{array}$ & $\begin{array}{l}2.66 \\
(2.04-3.25)\end{array}$ & - & - \\
\hline
\end{tabular}

CI: 95\% confidential interval, IQR: interquartile range, bDMARDs: biologic disease modifying anti-rheumaticdrugs, LBP: low back pain 
Conclusion: In our cohort, $5.78 \%$ of the patients $<45$ years with chronic low back pain had axial SpA (AS: 2.76\%; and nr-axSpA: 3.02\%). Approximately, one in every five patients had undiagnosed axial SpA. Original manuscript made in collaboration with Novartis Argentina S.A

Disclosure of Interests: Mayra Alejandra Tobar Jaramillo: None declared, Nicolas Marin Zucaro: None declared, Javier Rosa: None declared, Josefina Marin: None declared, Maria Laura Acosta Felquer: None declared, LEANDRO FERREYRA: None declared, JOHN FREDY JARAMILLO GALLEGO: None declared, Josefina Marcos Employee of: Novartis, Vanesa Duarte Employee of: Novartis, Enrique Soriano Speakers bureau: AbbVie, Amber, Bristol-Myers Squibb, Eli Lilly, Novartis, Pfizer Inc, Roche, Consultant of: AbbVie, Eli Lilly, GlaxoSmithKline, Novartis, Pfizer Inc, Sandoz, Grant/ research support from: AbbVie, Eli Lilly, GlaxoSmithKline, Novartis, Pfizer Inc, Sandoz.

DOI: 10.1136/annrheumdis-2021-eular.2391

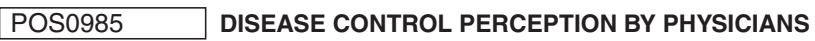 AND PATIENTS WITH ANKYLOSING SPONDYLITIS AND PSORIATIC ARTHRITIS IN REAL CLINICAL PRACTICE IN SPAIN: MIDAS STUDY RESULTS}

J. L. Pablos ${ }^{1}$, X. Juanola ${ }^{2}$, C. Barbazán ${ }^{3}$, M. L. García Vivar ${ }^{4}$, A. C. Valenciano ${ }^{5}$, C. Rodriguez-Lozano ${ }^{6}$, M. Estadella ${ }^{7}$, A. Venegas ${ }^{8}$, C. Sanabra ${ }^{8}$, C. Sastré ${ }^{8}$ on behalf of MIDAS group. ${ }^{1}$ Instituto de Investigación Hospital 12 de Octubre, Rrheumatology Service, Madrid, Spain; ${ }^{2}$ Hospital Universitari Bellvitge, IDIBELL, Rheumatology Service, L'Hospitalet de Llobregat, Barcelona, Spain; ${ }^{3}$ Complexo Hospitalario Universitario de Vigo, Rrheumatology Service, Vigo, Spain; ${ }^{4}$ Hospital Universitario Basurto, Rheumatology Service, Bilbao, Spain; ${ }^{5}$ Hospital Universitario Severo Ochoa, Rheumatology Service, Leganés, Madrid, Spain; ${ }^{6}$ Hospital Universitario de Gran Canaria Doctor Negrín, Rheumatology Service, Las Palmas de Gran Canaria, Spain; ${ }^{7}$ Syneos Health, Rheumatology, Barcelona, Spain; ${ }^{8}$ Novartis Farmacéutica, Rheumatology, Barcelona, Spain

Background: There are few published data regarding physician' and patient' perception of the disease control for ankylosing spondylitis (AS) and psoriatic arthritis (PsA).

Objectives: To evaluate the relationship between physician' and patient' disease control perception compared to clinical outcomes for controlled disease (BAS$\mathrm{DAl}<4$ in AS or DAPSA $\leq 14$ in PsA).

Methods: MIDAS is an observational, non-interventional, cross-sectional, multicenter study. Patients $\geq 18$ years with $\geq 6$ months AS or PsA diagnosis according to ASAS and modified New York criteria or CASPAR criteria, respectively, undergoing treatment $\geq 3$ months before inclusion. The endpoint of this analysis was the relationship between disease control perception by physicians and patients and disease control (BASDAI $<4$ in AS or DAPSA $\leq 14$ in PsA).

Results: 313 AS patients included: $75.7 \%$ male, $78.5 \%$ HLA-B*27+, a mean (SD) age of 50.4 (12.0) years, a mean (SD) disease duration of 15.5 (11.6) years and a mean (SD) CRP of 5.1 (8.2) $\mathrm{mg} / \mathrm{l} .313 \mathrm{PsA}$ patients included: $54.3 \%$ male, $17.95 \%$ HLA-B*27+, a mean (SD) age of 54.1 (12.2) years, a mean (SD) disease duration of $10.5(9.0)$ years and a mean (SD) CRP of 4.91 (7.3) $\mathrm{mg} / \mathrm{l}$. AS group: in $95.5 \%$ of AS patients with BAS$\mathrm{DAl}<4$, physician's perception matched the clinical evaluation, while only $42.3 \%$ of the patients with BASDAI $\geq 4$ matched physician's perception. Positive Predictive Value (PPV) was $75.1 \%$, Negative Predictive Value (NPV) was $83.9 \%$ and precision was $76.7 \%$. Patients perceived their own disease as controlled in $95.0 \%$ of cases with BASDAI scores $<4$ and as not controlled in $29.7 \%$ of cases with BASDAI score $\geq 4$. PPV was $71.1 \%$, NPV was $76.7 \%$ and precision was $71.9 \%$. The same trend was observed when assessing disease control through ASDAS-CRP index. PsA group: in $96.2 \%$ of patients with DAPSA $\leq 14$, physician's perception matched the clinical evaluation, while only $47.6 \%$ of patients with DAPSA $>14$ matched the physician's perception. PPV was $73.1 \%$, NPV was $89.6 \%$ and precision was $76.4 \%$. Patients perceived their own disease as controlled in $93.5 \%$ of the cases with DAPSA scores $\leq 14$ and as not controlled in $32.3 \%$ of the cases with DAPSA $>14$. PPV was $66.8 \%$, NPV was $77.4 \%$ and precision was $68.4 \%$. The same trend was observed when assessing disease control through the MDA criteria (Table 1).
Table 1. Physician's and patient's perception of the disease control related to disease control variables in AS and PsA

\begin{tabular}{|c|c|c|c|c|c|c|c|}
\hline & & \multicolumn{3}{|c|}{$\begin{array}{l}\text { Controlled disease by } \\
\text { physician's perception? }\end{array}$} & \multicolumn{3}{|c|}{$\begin{array}{l}\text { Controlled disease by } \\
\text { patient's perception? }\end{array}$} \\
\hline & & Valid N & $\begin{array}{l}\text { Yes } \\
\text { N (\%) }\end{array}$ & $\begin{array}{l}\text { No } \\
\text { N (\%) }\end{array}$ & Valid N & $\begin{array}{l}\text { Yes } \\
\text { N (\%) }\end{array}$ & $\begin{array}{l}\text { No } \\
\text { N (\%) }\end{array}$ \\
\hline \multicolumn{8}{|l|}{ AS } \\
\hline $\begin{array}{l}\text { Disease } \\
\text { control }\end{array}$ & $\begin{array}{l}\text { Controlled } \\
\text { (BASDAI }<4)\end{array}$ & $\begin{array}{l}202 \\
(100 \%)\end{array}$ & $\begin{array}{l}193 \\
(95.5 \%)\end{array}$ & $9(4.5 \%)$ & $\begin{array}{l}202 \\
(100 \%)\end{array}$ & $\begin{array}{l}192 \\
(95.0 \%)\end{array}$ & $\begin{array}{l}10 \\
(5.0 \%)\end{array}$ \\
\hline (BASDAI) & $\begin{array}{l}\text { Not controlled } \\
(\mathrm{BASDAl} \geq 4)\end{array}$ & $\begin{array}{l}111 \\
(100 \%)\end{array}$ & $\begin{array}{l}64 \\
(57.7 \%)\end{array}$ & $\begin{array}{l}47 \\
(42.3 \%)\end{array}$ & $\begin{array}{l}111 \\
(100 \%)\end{array}$ & $\begin{array}{l}78 \\
(70.3 \%)\end{array}$ & $\begin{array}{l}33 \\
(29.7 \%)\end{array}$ \\
\hline $\begin{array}{l}\text { Disease } \\
\text { activity }\end{array}$ & $\begin{array}{l}\text { Inactive } \\
(\text { ASDAS-CRP }<1.3)\end{array}$ & $\begin{array}{l}92 \\
(100 \%)\end{array}$ & $\begin{array}{l}90 \\
(97.8 \%)\end{array}$ & $2(2.2 \%)$ & $\begin{array}{l}92 \\
(100 \%)\end{array}$ & $\begin{array}{l}91 \\
(98.9 \%)\end{array}$ & $1(1.1 \%)$ \\
\hline (ASDAS-CRP) & $\begin{array}{l}\text { Active } \\
\text { (ASDAS-CRP } \geq 1.3 \text { ) }\end{array}$ & $\begin{array}{l}221 \\
(100 \%)\end{array}$ & $\begin{array}{l}167 \\
(75.6 \%)\end{array}$ & $\begin{array}{l}54 \\
(24.4 \%)\end{array}$ & $\begin{array}{l}221 \\
(100 \%)\end{array}$ & $\begin{array}{l}179 \\
(81.0 \%)\end{array}$ & $\begin{array}{l}42 \\
(19.0 \%)\end{array}$ \\
\hline \multicolumn{8}{|c|}{ 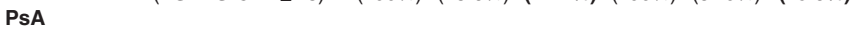 } \\
\hline $\begin{array}{l}\text { Disease } \\
\text { control }\end{array}$ & $\begin{array}{l}\text { Controlled } \\
\text { (DAPSA } \leq 14)\end{array}$ & $\begin{array}{l}186 \\
(100 \%)\end{array}$ & $\begin{array}{l}179 \\
(96.2 \%)\end{array}$ & $7(3.8 \%)$ & $\begin{array}{l}185 \\
(100 \%)\end{array}$ & $\begin{array}{l}173 \\
(93.5 \%)\end{array}$ & $\begin{array}{l}12 \\
(6.5 \%)\end{array}$ \\
\hline (DAPSA) & $\begin{array}{l}\text { Not controlled } \\
\text { (DAPSA>14) }\end{array}$ & $\begin{array}{l}126 \\
(100 \%)\end{array}$ & $\begin{array}{l}66 \\
(52.4 \%)\end{array}$ & $\begin{array}{l}60 \\
(47.6 \%)\end{array}$ & $\begin{array}{l}127 \\
(100 \%)\end{array}$ & $\begin{array}{l}86 \\
(67.7 \%)\end{array}$ & $\begin{array}{l}41 \\
(32.3 \%)\end{array}$ \\
\hline \multirow[t]{2}{*}{$\begin{array}{l}\text { Active disease } \\
\text { (MDA) }\end{array}$} & $\begin{array}{l}\text { Inactive } \\
\text { (MDA criteria } \geq 5 \text { ) }\end{array}$ & $\begin{array}{l}161 \\
(100 \%)\end{array}$ & $\begin{array}{l}154 \\
(95.7 \%)\end{array}$ & $7(4.3 \%)$ & $\begin{array}{l}160 \\
(100 \%)\end{array}$ & $\begin{array}{l}152 \\
(95.0 \%)\end{array}$ & $8(5.0 \%)$ \\
\hline & $\begin{array}{l}\text { Active } \\
\text { (MDA criteria<5) }\end{array}$ & $\begin{array}{l}151 \\
(100 \%)\end{array}$ & $\begin{array}{l}91 \\
(60.3 \%)\end{array}$ & $\begin{array}{l}60 \\
(39.7 \%)\end{array}$ & $\begin{array}{l}152 \\
(100 \%)\end{array}$ & $\begin{array}{l}107 \\
(70.4 \%)\end{array}$ & $\begin{array}{l}45 \\
(29.6 \%)\end{array}$ \\
\hline
\end{tabular}

AS, ankylosing spondylitis; ASDAS-CRP, Ankylosing Spondylitis Disease Activity ScoreC-reactive protein; BASDAI, Bath Ankylosing Spondylitis Disease Activity Index; DAPSA Disease Activity in Psoriatic Arthritis; MDA, Minimal Disease Activity; PsA, psoriatic arthritis.

Conclusion: A higher agreement between physician's and patient' perception with the current clinical evaluation was observed when patients were controlled. MiDAS study showed that in real clinical practice in Spain, physicians perceived more disease control than the patients

Acknowledgements: We thank to MIDAS group investigators and patients included in the study.

Disclosure of Interests: José Luis Pablos Speakers bureau: Janssen, Pfizer, Lilly, Novartis, Roche, Celgene, Bristol, Abbvie, Sanofi, Consultant of: Janssen, Pfizer Lilly, Novartis, Roche, Celgene, Bristol, Abbvie, Sanofi, Gilead, Galápagos, Xavier Juanola Speakers bureau: Novartis, Abbvie, Pfizer, Lilly, Consultant of: Novartis Lilly, Abbvie, Ceferino Barbazán Speakers bureau: Sanofi, Pfizer, Novartis, Amgen, Abbvie, Roche, Galápagos, Lilly, BMS, Biogen, UCB, Consultant of: Sanofi, Pfizer Novartis, Amgen, Abbvie, Roche, Galápagos, Lilly, BMS, Biogen, UCB, María L. García Vivar Speakers bureau: Lilly, Novartis, Pfizer, Amgen, Bristol, Abbvie, Sanofi, Janssen and UCB, Consultant of: Lilly, Novartis, Pfizer, Amgen, Bristol Abbvie, Sanofi, Janssen and UCB, Ana Cruz Valenciano Speakers bureau: Novartis, Consultant of: Novartis, Carlos Rodriguez-Lozano: None declared, Maria Estadella Employee of: I'm employed at Syneos Health providing services for Novartis. Ana Venegas Employee of: employee at Novartis, Cristina Sanabra Employee of: Novartis employee, Carlos Sastré Employee of: Novartis employee.

DOI: 10.1136/annrheumdis-2021-eular.2397

\section{\begin{tabular}{|l|l}
\hline POS0986 GENDER DIFFERENCES IN DISEASE CONTROL AND \\
\hline
\end{tabular} HEALTH STATUS IN PATIENTS WITH ANKYLOSING SPONDYLITIS IN CLINICAL PRACTICE IN SPAIN: RESULTS OF THE MIDAS STUDY}

C. Fernández-Carballido ${ }^{1}$, J. Gratacos-Masmitja ${ }^{2}$, E. De Miguel ${ }^{3}$, P. S. Del Río Martínez ${ }^{4}$, O. Martínez González ${ }^{5}$, A. Fernandez-Nebro ${ }^{6}$, P. VelaCasasempere $^{7}$, C. Sanabra ${ }^{8}$, C. Sastré ${ }^{8}$ on behalf of MIDAS group. ${ }^{1}$ Hospital Universitario San Juan de Alicante, Rheumatology Service, Alicante, Spain; ${ }^{2}$ Hospital Universitario Parc Taulí, Rheumatology Service, Sabadell, Spain; ${ }^{3}$ Hospital Universitario La Paz, Rheumatology Service, Madrid, Spain; ${ }^{4}$ Hospital Clínico Universitario Lozano Blesa, Rheumatology Service, Zaragoza, Spain; ${ }^{5}$ Hospital Universitario de Salamanca, Rheumatology Service, Salamanca, Spain; ${ }^{6}$ Hospital Regional Universitario de Málaga, Rheumatology Service, Málaga, Spain; ${ }^{7}$ Hospital General Universitario Alicante, Rheumatology Service, Alicante, Spain; ${ }^{8}$ Novartis Farmacéutica, Rheumatology, Barcelona, Spain

Background: Data on disease activity status and health status (HS) in clinica practice in Spain for patients with ankylosing spondylitis (AS) are scarce. The MIDAS study assessed the disease activity and the relationship with the reported HS in patients with AS treated in clinical practice in Spain. 